\title{
Choosing a Competitive Advantage Under the Constraints and Possibilities of the External Environment: An Empirical Study in the Retail Trade Sector in Elbasan, Albania
}

\author{
Teuta Hazizi (Balliu) \\ Lecturer, Departament of Business Administration, Faculty of Economy, "Aleksandër \\ Xhuvani” University, Elbasan, Albania \\ Florenca Gjorduni
}

Departament of Economics and Finance, “Aldo Moro” University, Italy, “Aleksandër Xhuvani” University, Elbasan, Albania

\begin{abstract}
The effects of macro and micro environmental on the decisions of choosing the operations strategy in the manufacturing industry are part of a number of scientific researches. In addition to this industry, the service industry, mainly in recent years, has attracted the attention of researchers, including the way it develops operations strategies. Based on the experiences of the manufacturing sector, in this paper we will try to analyze the relationships between external environmental factors and decisions on the choice of operations strategy. The conducted study highlights important relations between these variables. Thus, technology, as one of the most dynamic macro-environmental factors, through its elements such as retail computer systems or even innovations, dictates the choice of operations strategy. While other elements, such as labor supply does not appear to have the same impact as technology on choosing the right strategy of operations in the retail sector in our country. In order to prove the hypothesis raised in this study we used the factor and the path analysis. The primary data collected through the questionnaire built specifically for this study were processed with the SPSS program.
\end{abstract}

Keywords: External environment, operations strategy, retail trade

\section{Introduction}

The external environmental, which is increasingly presented to us as dynamic and complex, operates outside the boundaries of organizations and affects their operations. These factors reflect the conditions and trends of the society within which business organizations operate. All together, whether micro or macro, they dictate restrictions and offer different opportunities. Management becomes even more effective with a careful recognition and study of these factors, in order not only to avoid the undesirable effects generated by them, but also to exploit their potentials.

Companies seeking success in today's market, which is already known as a highly competitive market, must, among other things, formulate operations strategies in accordance with the external environment with which they interact. 
Operations strategies focus on how competition is changing and at the operations that need to be carried out, so that companies successfully meet current and future challenges. They also relate to the development and long-term improvement of the operations processes and resources in order to build the foundations for competitive advantages. If a business does not properly assess the strategic effects that effective management of operations and processes has, we can say that it is bypassing a very good opportunity for success. In other words, those businesses that seem to compete successfully, or have sustainable success in the long run definitely have clear, innovative operations strategies and in accordance with the environment in which they live.

Ward and Duray developed a conceptual model that established a relation between the business environment, competitive and operational strategies as well as high performance (Ward, P.T. and Duray, R., 2000). Furthermore, other researchers have conducted similar studies for developing countries in order to identify the environmental elements that influence the operations strategies implemented by manufacturing companies. (AmoakoGyampah, K. and Boye, S.S., 2001)

Part of the group of factors that require management attention are the increase of business costs, the increase of consumer awareness, the uncertainty or unpredictability of competitors' actions, the consumer preferences, the improvement of transport efficiency and logistics, as well as the governments' pressures, regulatory supervisors, trade unions and developments in information and communication technologies. (Lo, T.W., Lau, H.F. and Lin, G., 2001)

Our country, due to the considerable number of small businesses, the number of which in 2018 was 162835 businesses of which 93 048, or 57\%, are sole proprietorship, offers sufficient space for researches of this kind. In the retail sector, according to the Institute of Statistics (December 2018), the sales index increased by $3.7 \%$ on an annual basis. This is the highest retail growth in recent years.

This study is focused on retail sector in Elbasan. Elbasan is a city n the very center of Albania. Its population is around 270000 citiziens and 13400 active enterprises. Its purpose is to investigate how different environmental factors influence the choice of competitive operations strategies in terms of coping with a harsh, complex and dynamic environment. We will try to identify specific relationships between elements of the external environment, such as business costs, labor supply, competition and technology, and the content of operations strategy which focuses on the competitive advantages of a business organization, such as low cost, quality, flexibility and delivery.

\section{Literature review}

Fierce competition, technological developments, consumer preferences and perceptions, regulatory background, the lack of stability in fiscal and monetary policy, trade unions and the increasingly difficult relations with suppliers make the environment in which organizations operate an equally complex and dynamic one. External environmental factors are factors that operate outside the boundaries of an organization and that affect its operations. The spectrum of macro and micro environmental elements reflects the conditions and trends of the society within which the business organization operates. Managers study these factors not only to avoid their undesirable effects, but also to effectively exploit the potential opportunities created by them. (LLaci, 2010, p. 39). Thus, for example, if we refer to the laws and regulations in force, it can be noticed that when businesses operate in countries with strong laws and regulations, they tend to search and find out more about strategies (Santema, S.C. \& Hoekert, 
Marijke \& Rijt, Jeroen \& Oijen, Aswin., 2005). The same authors note that companies with a centralized decision-making structure pay less attention to research on strategies, as it is believed that by being more centralized they are informed more efficiently using other channels rather than strategies. The businesses in countries, whose societies are afraid of the uncertainty of the future and who try to avoid it and the risks that it is accompanied by, need more rules and laws. Societies that do not avoid the risk and the uncertainty of the future are more open and welcome the challenges of competition and convey more and more information to the public (SP, 2012).

Various researchers have concluded that operations strategies are an important contributor to successful business competition in both domestic market and exports (Singh, H., \& Mahmood, R., 2014). High productivity of the production function is seen as a key contributor to business success (Singh, Sanjay \& Kagalwala, Mohamedi \& Parker-Thornburg, Jan \& Adams, Henry \& Majumder, Sadhan, 2010). This importance has been studied together with the ability of strategy to adapt to environmental changes generated by technology and market demand fluctuations (Dombrowski, Stephan \& O’Carroll, Ronan \& Williams, Brian., 2016).

On the other hand, the strategy is conceived as a managerial mechanism used to reach conclusions which coincide with the company's mission and objectives (Hitt, Michael \& Ireland, R. \& Hoskisson, Robert., 2013). Functional level strategies support business and corporate objectives and strategies; they are the competitive advantages that the company possesses. Manufacturing operations support business and corporate strategy by providing resources and conditions to achieve its objectives (Slack, 2007). The unique architecture of each strategy is what ensures an essential strategic contribution to achieve and maintain a competitive advantage. All this leads us to conclude that business organizations do not have one, but several operations strategy. Each of them has a unique and individual emphasis that is dictated by a number of factors such as trading partners, supply system configuration, costs, demand behaviors, etc (Venetike Nakuçi, Ali Turhani, 2012).

Each of the performance objectives has an external aspect, which leads to customer satisfaction, and an internal aspect, which leads the organization to efficiency and sustainability. Quality, for example, is the most visible part of what an operation does. High quality products and services mean higher customer satisfaction and therefore the customer is expected to return again. Speed is related to the time customers have to wait for receiving their products and services, but also to the value of the goods on the shelfs.The speed target brings among other things, even the reduction of the inventory and risk. If we refer to reliability or security we could interpret it as the security that customers receive goods and services when promised. Security saves the organization time and money, and gives stability. The vast majority of operations performed by a business organization are able to change in order to meet the requirements of its customers. This ability to change is related to the competitive advantage of flexibility, ie the ability to offer a wide range of products and services, by changing the level of production and activities carried out. The flexibility speeds up the response, saves time and maintains the certainty that operations will take place as planned. When treating cometititve advantages we can not ignore costs as one of the most long-standing advantages. If business organizations compete directly on price, low cost will undoubtedly be their main objective. The way a manager influences the costs of operations depends largely on the origin or place where they arise. In this way, cost structures and categories take on special importance. Cost is affected by all the performance objectives mentioned so far, therefore within the operation, one of the ways to improve the cost is exactly 
the performance improvement of other objectives, namely quality, safety, delivery and flexibility.

The need to adapt the operations strategy to external environmental factors is supported by some empirical studies, which show that different environmental dimensions make manufacturing and service organizations react differently. The mediating effect of competitive strategy suggests that environmental dynamism has a significant impact on production strategy, but this impact is articulated through and modified by competitive strategy (Ward, P.T. and Duray, R., 2000). Other authors have identified strong relationships between environmental factors, such as labor supply, fierce competition, state laws and regulations, political concerns, and market dynamism with operations strategies included by competing priorities (Badria, M.A., Davis, D. and Davis, D, 2000). The unpredictability parameters or instability of environmental dynamics play a crucial role in determining the types of flexibility strategies (Anand, G. and Ward, P.T., 2004). High environmental dynamism fosters more operations strategies, which further emphasizes the need for high delivery performance, flexibility and competitive quality priority. Due to the proximity of the service business to customers, service operations need to be extremely sensitive to customers and markets. The operations strategy needs to be changed and adapted to maximize market criteria for success and to choose strategic dimensions such as efficiency, price, effectiveness, quality and flexibility as required by the market.Variables such as stock, physical space of the sales environment, the system in terms of operations recovery, standards and staff, otherwise known as 5Ss, are recognized as essential drivers of the benefits of this type of business (Pal A John and Byrom W John, 2003).

The operational mediocrity is due to a lack of knowledge on the real availability in the store and out-of-stock situations at the point of sale and the ignorance of the consequences that these situations create (Raman, A. \& Dehoratius, N. \& Ton, Z., 2001). The current debates point to the fact that the combination of production factors in the grocery retail; such as staff, space, assortment, etc, are what explain the existence of certain types of retail stores, and lead to specific outputs. Sometimes these factors are the reason why some of these businesses operate with very low profit margins. What we want to emphasize is the fact that the consequences of the lack of effectiveness in operations and related strategies are evident. The discussion on retail operations should not be avoided, rather it should be given more attention by researchers and not only. Nowadays retailers face up and take quite complex decisions. Decisions involving not one but several issues, such as deployment, assortment, target market selection, supplier negotiation, challenge motivation, technological innovation, competition, applicable laws and norms, all of these are now realized under a competitive and global environment. (Michael Leavy and Barton A.Weitz, 2001).

\section{Retail sector in Albania}

The high informality and unfair competition are the main issues facing the retail market in our country. Lack of market regulations and operation outside any standards, especially in food industry is one of the problems. Creating, respecting and controlling standards would create a more efficient and effective operation, increase quality, service, security, promote international trade, etc (Qefalia, 2010). Albania is part of a group of countries with a very high degree of informality and, consequently, tax evasion. The black economy at these levels has brought negative effects related to unfair competition, created by businesses that evade taxes (Teuta Balliu, Aida Gaçe, Mimoza Kotollaku, Vol 1, Issues 2, 2012). 
According to the EU Council data during 2018, 55\% of Albanian businesses have had an annual turnover of up to 500000 Euros, a study which emphasizes once more the importance of this sector in the Albanian economy ( https://ec.europa.eu/docsroom/documents/38667).

The same study of the Council of Europe states that the biggest problems faced by business in our country are related to the skills of employees and experienced managers, competition, finding clients and costs, which includes both labor costs and production costs ( https://ec.europa.eu/docsroom/documents/38667). The World Bank estimates that eventhough Albania has adopted a wide variety of rules to monitor abuses; their implementation remains weak due to ongoing informality in the workforce. According to the business environment observation and enterprise performance, competition from the informal sector was the second biggest problem for Albanian companies. More than $40 \%$ of firms surveyed by the World Bank reported competing against informal firms in the sector. This unfair competition is high among SMEs, as $41 \%$ of them report competing with unregistered businesses compared to $27.8 \%$ of large firms.

On the other hand, according to the Institute of Statistics, INSTAT, for 2019, the sales volume index in the retail trade has increased by 3.5\%, compared to the same quarter of the previous year, this in excluding the retail trade of hydrocarbons. The group of "Food, beverages, tobacco in non-specialized and specialized trade units", has on increase by $3.2 \%$ in the sales volume index, compared to the same quarter of 2018. The sales volume index, for the group "Non-food items in specialized and non-specialized trade units", has increased by 3.8\% compared to the same period of the previous year. As for the group "Trade of hydrocarbons in specialized trade units", the sales volume index increased by $2.3 \%$, compared to the same quarter of 2018. In the first quarter of 2019 , the seasonally adjusted sales volume index, in the group "Retail trade, excluding retail trade of hydrocarbons in specialized units", has not changed compared to the fourth quarter of 2018. The seasonally adjusted sales volume index in "Food, beverages, tobacco in non-specialized and specialized trade units" group increased by $0.3 \%$ compared to the previous quarter. The sales volume index, seasonally adjusted, in retail trade, for the group "Non-food items in specialized and non-specialized trade units", has increased by $0.7 \%$ compared to the previous quarter. In the group "Retail sale of hydrocarbons in specialized trade units", the seasonally adjusted sales volume index, increased by $2.5 \%$ compared to the fourth quarter of 2018.

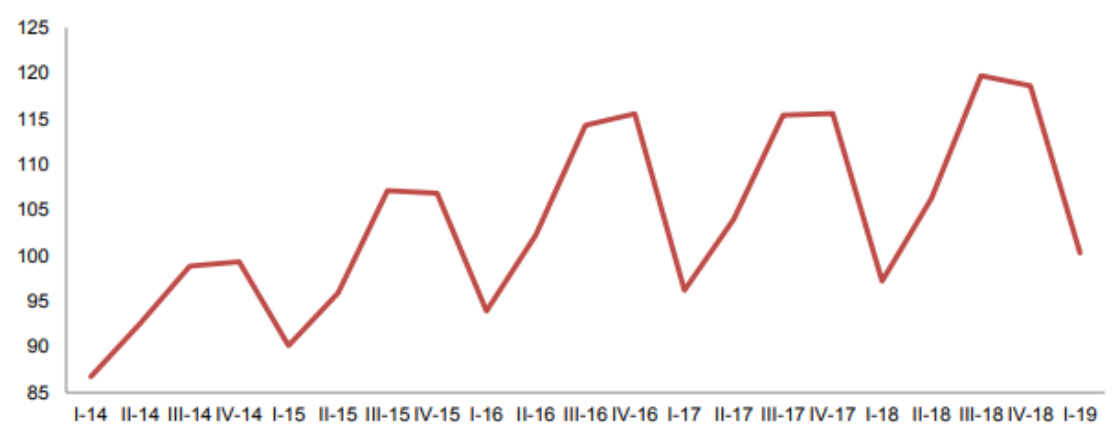

Graph 1: Retail trade volume index 


\section{Methodology}

I order to carry out this study we initially developed a conceptual structure to link the business environment and operations strategy (see Figure 1). This framework defines the business environment as a potential driving force in choosing the appropriate operations strategy. The business environment is presented by four factors which are not controlled by the management of business organizations, such as business cost, labor supply, competition and technology. Meanwhile the operations strategy reflects one or more of todays four competitive advantages, low cost, quality, flexibility and delivery.
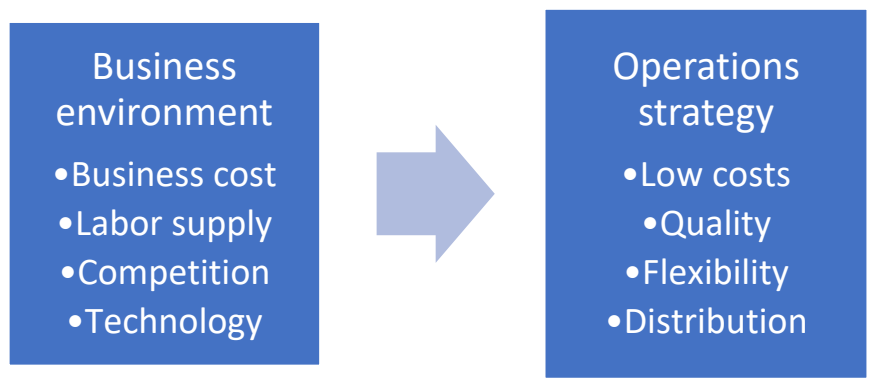

Figure 1: Conceptual structure of linking environment to the strategy of operations

There are a number of studies that have developed conceptual models that link the business environment to operations strategy, and among them there are researches where environmental factors are explicitly involved in the study of service operations strategies, especially in small and medium business. Therefore, it is worthwhile to continuously encourage research linking the business environment with the operations strategy in the retail sector.

The research question of this study relates to how environmental elements influence the selection of operations strategy.

Its hypotheses are constructed precisely with reference to the above structure. Their aim is to examine the specific nature of any relationship that exists between the constraints and opportunities of the business environment and the dynamics, and the operational strategies selected by the business itself. We are interested to know if there are direct paths between each of the external environmental factors and the choices of previously identified operational strategies. In order to understand the nature of the relationship between these factors the following hypotheses have been raised:

$\mathrm{H}_{1}$ : Business cost has a significant impact on the choice of operations strategy with low cost, quality, flexibility and fast delivery.

$\mathrm{H}_{2}$ : The labor supply has a significant impact on the choice of strategy of operations with low cost, quality, flexibility and fast delivery.

$\mathrm{H}_{3}$ : Competition has a significant impact on the choice of strategy of operations with low cost, quality, flexibility and fast delivery.

$\mathrm{H}_{4}$ : Technology has a significant impact on the choice of low cost operations strategy, quality, flexibility, and fast delivery. 
Descriptive and analytical analyzes have been used to achieve the purpose of this quantitative research, and the data used are primary and secondary ones. The secondary data are obtained from various literatures in the field of business management, operational management and operational strategies. Whether the primary data were provided by a questionnaire built specifically for this paper. They were further processed with the statistical program SPSS. Factor analysis and statistical analysis SEM (Structural equation modeling) were used to analyze the data and derive its results. The data were provided by business organizations in the retail sector in the city of Elbasan. The sample consisted of retail traders operating in both the food and non-food sectors. A total of 120 questionnaires were distributed, of which 83 were completed, a figure that shows about $69.1 \%$ of the answers. After reviewing them, we found that 9 out of 83 questionnaires were not completed properly and could not be used, concluding that 74 questionnaires were further analyzed. Four dimensions are included in this study certainly referring to previous studies. These dimensions are conceptually related not only to the obstacles or difficulties, but also to the facilities offered by the external environment:

business costs, or otherwise concerns about the rising cost of inputs in the operations process, for example labor, rent, transportation and utility costs.

labor supply, often referred to as job availability, which is mainly related to concerns about market shortages of skilled workers and technicians, as well as managerial and administrative workers.

competition as a reflection of concerns about changes in the market such as increased competition, declining demand for products, low profit margins, tougher quality standards set by the market, and the division of state laws and regulations.

technology which as a whole can be seen as current production knowledge of products and services. Its impact is reflected in new products, modern machinery and equipment as well as new services. The technological changes of recent years and their application on decisionmaking have completely changed the nature of the workplace. Technological factors will become even more important in the future. Technology as one of the most dynamic elements of nowadays is analyzed referring to the technological sales system, electronic data exchange system which enables business-to-business connection as well as new logistics systems which refer to the speed of response todemand side in order to keep pace with demand and coded commodity bars which enable unique identification and tracking of all components and products through a supply chain.

As we have previously pointed out, the strategy of operations is related to the competitive advantage in the market, and this is why we are focused on today's four competitive advantages, which are widely used as measuring instruments of operations strategies. More specifically we focused on cost, quality, delivery and flexibility.

The questionnaire used the "importance scale" that an organization gives to an element in order to remain competitive. (Kirsty Williamson, Graeme Johanson, 2017). Scales range from from 1 or "not at all important" and up to 5 or "very important". We used four questions to assess low cost, looking at the degree of importance placed on reducing high-level costs, inventory levels, and increasing utilization of equipment and private sales. Quality was assessed with three more questions. The questions were focused on the extent of importance attached to providing appropriate specifications about goods and services, improving the 
performance and reliability of goods or services, and the managerial function of quality control of goods and services, requiring suppliers to pass a formal certificate of quality control and improvement system. We have tried to analyze the delivery performance by the speed, reliability as well as the improvement of the service after the purchase. We also tried to explain flexibility through the flexibility of goods and services, the mix of flexibility, the flexibility of volume and the flexibility of offers.

\section{Results}

All the questionaris were fulfilled by difeerent business manager. All of them have more than five years experience in the retail sector.

Structural equation modelling (SEM) includes, among others, as special cases path analysis and covariance structure analysis. Path analysis is an extension of the regression model, used to "test the fit of the correlation matrix against two or more causal models which are being compared by the researcher". The model is usually depicted in a circle-andarrow figure in which single arrows indicate causation. Path analysis offers some distinct advantages including the identification of direct and indirect effects in a complex system of variables, and the convenience with which intervening variables could be included in the model. Ward and Duray (2000) employed a path model to link environment, competitive strategy, manufacturing strategy and performance (Ward, P.T. and Duray, R., 2000). So, we decided that path analysis would be an appropriate technique to use in this research. The results of data analysis are presented below. First the results of exploratory factor analysis (EFA) and confirmatory factor analysis (CFA) are reported. Then, we examine the impacts that environmental factors have on the operations strategy choices through the path analysis.

\section{Exploratory factor analysis (EFA)}

Principal component analysis with an oblique rotation was first undertaken on business environment and operations strategy measures to examine the underlying dimensions of the constructs. Factor analysis for the environmental factors produced four dimensions with eigenvalues greater than one (see Table 1). Moreover, Table 2 shows the results of operations strategy choices encompassed by competitive priorities. As shown in Table 1 and 2, some business environmental variables were deleted in analyze because of the low reliability.This might have occurred due to unique business culture in our retail industry, sample size, and perception of the respondents. Cronbach's alpha coefficient was used to examine the reliabilities among the items within each factor. If slpha coefficient is higher than 0.60 , generally is considered acceptable. From Table 1, we can see that the loadings of the first four factors were larger than 0.60 , representing an acceptable significant level of internal validity. The first factor including two items was entitled business cost. The second factor contained three items that reflected the labour offer. The next factor, competition, included two items that related to demanding quality standards as well as government laws and regulations. The next factor, labelled technology, contained three items including rate of changes in retail technology and innovation of new service development. Since all these four factors loadings were of an acceptable significant level, all these items were retained for further analysis. The factors who have indicated a low reliability (below 0.60 ) were excluded from further analyses. The item ECOST3 - rising transport cost was also deleted from further analysis, since it had significant loadings in more than one factor. 


\begin{tabular}{|c|c|c|}
\hline Variables & $\begin{array}{c}\text { Factor } \\
\text { Loandings }\end{array}$ & Alpha e Cronbach \\
\hline Factor 1: Business cost & & 0.623 \\
\hline ECOST1 - Work cost & 0.764 & \\
\hline ECOST2 - Rent cost & 0.699 & 0.636 \\
\hline Factor 2: Labor offer & & \\
\hline EGP1 - Managerial and administrative expenses & 0.798 & \\
\hline EGP2 - Techniciants expenses & 0.765 & 0.646 \\
\hline EGP3 - Skilled worker expenses & 0.744 & \\
\hline Factor 3: Competition & 0.841 & 0.696 \\
\hline ECON4 - High quality standards & 0.865 & \\
\hline ECON5 - Laws and regulations & & \\
\hline Factor 4: Technology & 0.723 & \\
\hline ETEC1 - Online sales & 0.825 & \\
\hline ETEC2 - Changing retail technology & 0.728 & \\
\hline ETEC3 - Service inovations & & \\
\hline
\end{tabular}

Table 1: Factor Loadings of Business Environment (EFA)

As shown in table 2, the 13 items of operations strategy loaded on four factors. The items loaded on the first factor, low cost, involved the operations strategy of reducing operations cost. The second factor, quality, included three items about providing high quality products and services for customers. The third factor reflects the competitive priority of flexibility. The last factor includes three items about offering reliable and fast delivery and after sales service for customers, and was named delivery. The alpha coefficients for the four factors were 0.642 , $0.594,0.680$, and 0.861 respectively. These values are either close to or exceed 0.60 criterion generally considered adequate for exploratory work.

\begin{tabular}{|c|c|c|}
\hline Variables & $\begin{array}{l}\text { Factor } \\
\text { Loadings }\end{array}$ & $\begin{array}{l}\text { Cronbach } \\
\text { alpha }\end{array}$ \\
\hline Factor 1: Low cost & & 0.642 \\
\hline COST1 - Reduce general cost & 0.792 & \\
\hline COST2 - Reduce inventory cost & 0.796 & \\
\hline COST3 - Increase the utilazion of the equipments & 0.634 & \\
\hline COST4 - Increse direct sales & & \\
\hline Factor 2: Quality & & 0.594 \\
\hline QUAL1 - The right specifications for the goods and services & 0.776 & \\
\hline $\begin{array}{l}\text { QUAL2 - The I mprovment of the reliability and goods } \\
\text { performance }\end{array}$ & 0.792 & \\
\hline $\begin{array}{l}\text { QUAL3 - Technics for controlling the quality of goods and } \\
\text { services }\end{array}$ & 0.662 & \\
\hline Factor 3: Flexibility & & 0.680 \\
\hline Flex 1 - Improving the changing of goods and services & 0.687 & \\
\hline $\begin{array}{l}\text { Flex } 2 \text { - Responding quickly to demand shifts and operational } \\
\text { changes }\end{array}$ & 0.821 & \\
\hline $\begin{array}{l}\text { Flex3 - Changing dates delivery plans with costomer or other } \\
\text { chain units }\end{array}$ & 0.776 & \\
\hline Factor 4: Delivery & & 0.861 \\
\hline DELIV 1- Fast delivery & 0.801 & \\
\hline
\end{tabular}




\begin{tabular}{|l|c|l|l|}
\hline & DELIV 2 - Delivery promises & 0.886 & \\
\hline & DELIV 3 - After sales services & 0.912 & \\
\hline
\end{tabular}

Table 2: Factor loading of operations strategy (EFA)

We used the hypothesized model to test model fitness by performing a Confirmatory Factor Analysis (CFA) on the survey data. In assessing model adequacy, we used several recommended tests: the Chi-square value normalized by degrees of freedom $(\chi 2 / \mathrm{df})$, the root mean square error of approximation (RMSEA), the comparative fit index (CFI), and the goodness-of-fit (GFI). A GFI and CFI greater than 0.90 are generally considered as a satisfactory fit, a value greater than 0.95 as a very good model fit. An RMSEA between 0 and 0.05 indicates a good fit and that between 0.05 and 0.08 an acceptable one. And, the Chi-square value normalized by degrees of freedom ( $\chi 2$ /df) should not exceed 3.

\begin{tabular}{|c|c|c|c|}
\hline & Variables & Variance explained (\%) & Cronbach alpha \\
\hline \multicolumn{4}{|c|}{ Business enviorment } \\
\hline 1 & Business cost & 72.248 & 0.623 \\
\hline 2 & Labor offer & 61.221 & 0.636 \\
\hline 3 & Competition & 73.865 & 0.646 \\
\hline 4 & Thechnology & 65.298 & 0.696 \\
\hline \multicolumn{4}{|c|}{$\begin{array}{c}\text { Goodness of Fit Statistics: } \chi^{2}=35.284 ; \mathrm{df}=35 ;\left(\chi^{2} / \mathrm{df}\right)=1.008 ; \text { RMSEA }=0.038 ; \mathrm{CF} 1=0.953 ; \\
\text { GFI }=0.929\end{array}$} \\
\hline \multicolumn{2}{|r|}{ Operations Strategy } & & \\
\hline 5 & Low cost & 58.698 & 0.637 \\
\hline 6 & Quality & 63.108 & 0.589 \\
\hline 7 & Flexibility & 60.521 & 0.676 \\
\hline 8 & Delivery & 76.987 & 0.839 \\
\hline \multicolumn{4}{|c|}{$\begin{array}{c}\text { Goodness of Fit Statistics: } \chi^{2}=79.352 ; \mathrm{df}=57 ;\left(\chi^{2} / \mathrm{df}\right)=1.392 ; \text { RMSEA }=0.056 ; \mathrm{CF} 1=0.929 ; \mathrm{GFI}= \\
0.908\end{array}$} \\
\hline
\end{tabular}

Table 3: Summary of fit statistics

As shown in Table 3, the results of CFA provided significant support for business environments conceptualizations $(\chi 2=35.285 ; \mathrm{df}=35 ;(\chi 2 / \mathrm{df})=1.008$; $\mathrm{RMSEA}=0.038 ; \mathrm{CF} 1=0.953 ; \mathrm{GFI}=$ 0.929). Table 3 also indicates that CFA results provided good fit for the four-factor (low cost, quality, flexibility and technology) solution for operations strategy. Hence, these results can be considered significant in statistical terms.

\section{Path analyses}

The results of path analyses are shown in fig. 2. The path coefficients (standardized regression coefficients) are shown on the arrows. The path analytic model indicates that the technology has the direct positive and significant effects on the degree of emphasis placed on low cost $(\beta$ $=0.62, \mathrm{p}<0.01)$, quality $(\beta=0.47, \mathrm{p}<0.01)$, and flexibility $(\beta=0.55, \mathrm{p}<0.01)$. The data also suggest that the predictors of quality are competitive and technology. Competitive has a 
slightly significant impact on the choice of quality as a component of operations strategy $(\beta=$ $0.25, \mathrm{p}<0.10$ ). As we can be see, business cost appears to slightly influence the operations strategy choices of delivery performance $(\beta=0.228, p<0.10)$. However, environmental concern about labour offer does not appear to have any direct effect on the operations strategy selections. Our hypotheses relating business environmental factors and operations strategy choices require the existence of at least one path between an environmental dimension and an operations strategy choice. The observed positive and significant direct impacts of the environmental dimensions on the operations strategy indicated that $\mathrm{H} 1, \mathrm{H} 3$, and $\mathrm{H} 4$ can not be rejected, but $\mathrm{H} 2$ can be rejected. Business environmental factors, including business cost, competitive, and technology, appear to affect operations strategy selections made by retail firms in our country. Labour offer has no direct significant effects on any of the operations strategy choices.

Figure 2: Path model of business environmental factors and operations strategy choices

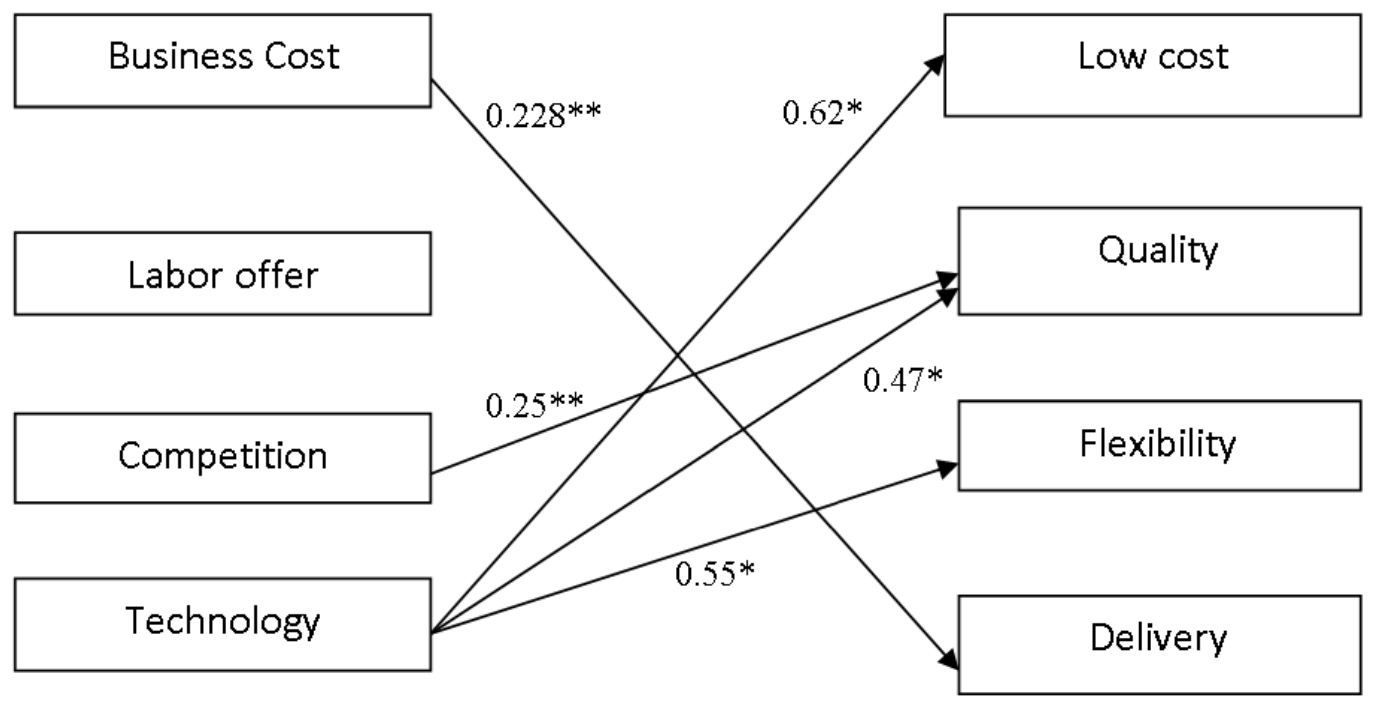

$$
\chi 2 / \mathrm{df}=1.028 ; \mathrm{RMSEA}=0.028 ; \mathrm{CF} 1=0.976 ; \mathrm{GFI}=0.871 * \mathrm{p}<0.01 ; * \mathrm{p}<0.10
$$

\section{Discussion and Conclusion}

In this paper we have observed some important paths or links between the dimensions of the business external environment and the strategies of operations performed by retail businesses. One of our findings is that business cost has a significant direct impact on delivery performance. The cost of doing business in our country is increasing. Increased rental and transformation costs and current global crisis add to the cost of doing business. Various studies point out that business cost is the difference that has a significant effect on distribution performance between different businesses. Similarly, service and retail sector businesses which face rising business costs also responded with a greater emphasis on delivery performance.

The pathways model also suggests that businesses retail sector facing tough competition put more emphasis on quality. Consumers, especially in big cities, are becoming smarter and more 
demanding in terms of quality and variety. More and more consumers have started to pursue better quality of life through higher quality products and fashion clothing.

The analysis also shows that technology has the most significant impact on operations strategy choices, affecting three out of four choices. It has strong positive effects on the degree of emphasis placed on low cost, quality and flexibility. Some of the strategic retail responses to technology are: increasing emphasis on cost reduction, quality and flexibility. Currently, retail trade faces several challenges such as; the growing need for information, innovation and faster development cycles and more difficulty in forecasting customer, product and service requirements. Moreover, with the development of the retail market, information technology will have an impact on the overall business efficiency of retailers and will affect operations ranging from online purchases to procurement and supply chains. Thus, retail traders aiming to succeed in the retail market need to consider technology, reduce operations costs through the effective application of information and technology, and create new products and services, and amazing results for their customers. However, the pathway model suggests that labor supply has no significant direct effects on any of the operations strategy solutions in this sector. This is not surprising when we consider the current business environment in which retailers operate in our country. Most retail traders that respond to the questionnaire may not feel that they are facing a critical job shortage, referring to the skills or qualifications needed by typical retail employees.

In order to survive in a complex and dynamic environment, appropriate environmental considerations must be considered when a firm develops a comprehensive operations strategy. Retail trade should be very careful about the current dynamic market environment, especially when developing effective and efficient operations strategies, such as providing customers with high quality products and services, reducing operating costs, and improving flexibility. Retail businesses need to provide reliable and fast delivery and increase after-sales service for their customers if they want to reduce the costs of doing business.

An important limitation of this research is that some variables, which we initially thought might be relevant to the business environment, had to be excluded due to low reliability. This may be a result of the unique characteristics of the retailer, the sample size and the different perception of the respondents. Furthermore, eventhough all businesses involved are retail tradeers, the following study should consider the fact that the market, services, and operations strategy are very different among retailers to respond to the same environmental stimulus.

This study is conducted in the retail sector as a whole; further researches can take into consideration that the market, the services, and the operational strategies are really different among different retailers such as supermarkets, clothes and others, and maybe they react differently to the same enviormental factor.

\section{Bibliography}

[1] https://ec.europa.eu/docsroom/documents/38667. (n.d.).

[2] Amoako-Gyampah, K. and Boye, S.S. (2001). "Operations strategy in an emerging economy: the case of the Ghanaian manufacturing industry". Journal of Operations Management, Vol. 19 , pp. pp. 59-79.

[3] Anand, G. and Ward, P.T. (2004). Fit, flexibility and performance in manufacturing: coping with dynamic environments". Production and Operations Management, Vol. 13 No. 4 , pp. 369-385. 
[4] Badria, M.A., Davis, D. and Davis, D. (2000). "Operations strategy, environmental uncertainty and performance: a path analytic model of industries in developing countries". Omega, Vol. 28 , pp. 155-173.

[5] Dombrowski, Stephan \& O'Carroll, Ronan \& Williams, Brian. (2016). Form of delivery as a key 'active ingredient' in behaviour change interventions. . British Journal of Health Psychology. 21. , pp. 733-740.

[6] Hitt, Michael \& Ireland, R. \& Hoskisson, Robert. (2013). Strategic Management: Competitiveness and Globalization. . Thomson South-Western.

[7] Kirsty Williamson, Graeme Johanson. ( 2017). Research Methods . Chandos Publishing.

[8] LLaci, S. (2010). Manaxhimi. Tiranë: albPAPER.

[9] Lo, T.W., Lau, H.F. and Lin, G. (2001). "Problems and prospects of supermarket development in China". International Journal of Retail \& Distribution Management, Vol. 29 No. 2 , pp. pp. 66-75.

[10] Michael Leavy and Barton A.Weitz. (2001). Retailing Management. McGraw-Hill.

[11] Pal A John and Byrom W John. ( 2003). " The Five Ss ofRetail Operations:- A model and tool for improvement. International Journal ofRetail and Distribution Management, Vol No 31, No 10 , pp No 518-528.

[12] Qefalia, A. (2010). Manaxhimi i Cilësisë Totale. Tiranë: Expo Vision Albania.

[13] Raman, A. \& Dehoratius, N. \& Ton, Z. (2001). The Achilles' heel of supply chain management. Harvard Business Review. 79 , 25-28.

[14] Santema, S.C. \& Hoekert, Marijke \& Rijt, Jeroen \& Oijen, Aswin. (2005). Strategy disclosure in annual reports across Europe: A study on differences between five countries. . European Business Review. 17 , pp. 352-366.

[15] Singh, H., \& Mahmood, R. (2014). Cobined effect of competitive and manufacturing strategies on export performance of SMEs in Malaysia. Global Journal of Management and Business Research, 14(1) , pp. 99-106.

[16] Singh, Sanjay \& Kagalwala, Mohamedi \& Parker-Thornburg, Jan \& Adams, Henry \& Majumder, Sadhan. (2010). Singh et al. reply. p. Nature 467(7311):E5.

[17] Slack, N. (2007). Operations Management. Financial Times / Prentice Hall.

[18] SP, W. (2012). 'The impact of culture on risk management disclosures : an exploratory study of international banks', DBA thesis. Southern Cross University, Lismore, NSW: SP Wong 2012.

[19] Teuta Balliu, Aida Gaçe, Mimoza Kotollaku. (Vol 1, Issues 2, 2012, Gusht). The Economic Informallity Opposite Fiscal Policy and the Legal Vacuum Issues. the Features of the Tourism Sector Informallity in Albania. European Journal of Economics and Business Studies, pp. 77-82.

[20] Venetike Nakuçi, Ali Turhani. (2012). Strategjitë e operacioneve. Tiranë: Grafon.

[21] Ward, P.T. and Duray, R. (2000). "Manufacturing strategy in context: environment, competitive strategy and manufacturing strategy". Journal of Operations Management, Vol. 18, , pp. pp. 123138. 